\title{
OBITUARIES/HULDEBLYKE
}

\section{Ajay Makanjee}

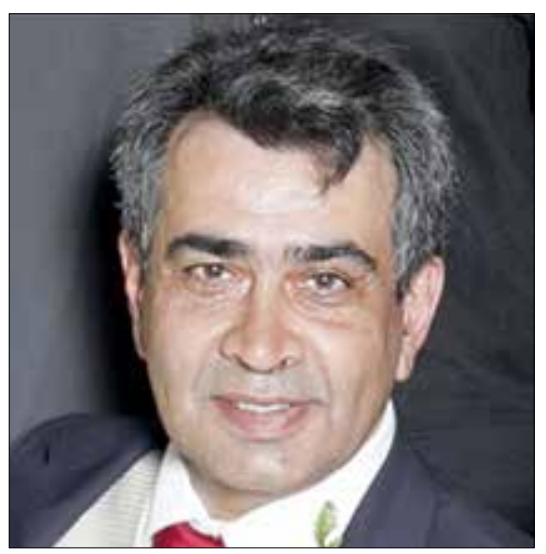

This tribute to Dr Ajay Makanjee, general surgeon and founding member of the KwaZulu-Natal Specialist Network, was extracted from a eulogy at his memorial service.

Ajay was born in Durban to Jaymati and Amaratlal Makanjee on 13 November 1959. He matriculated at the Gandhi Desai School in Durban and then attended medical school at the University of Natal, graduating in 1982.

At medical school, his habit of questioning his teachers whenever he saw a reason to challenge their views raised the ire of many. $\mathrm{He}$ also refused to attend lectures that he considered mundane, preferring to study those subjects on his own. He was a master brag and table-tennis player, and spent many hours in the medical school sports hall honing his skills.

Ajay had a strong intuitive sense of ethics, and when the United Nations promulgated International Woman's Day to highlight the plight of women, Ajay wrote a letter to request that they also found an International Youth Day.

In 1990 he qualified as a general surgeon. With a special interest in diseases of the breast, he was a founding member and remained actively involved in the metropolitan breast oncology team in Durban. Such was his dedication to this team that he attended his last clinic the day before his sudden illness.

Known for his formidable intellect and irreverent sense of humour, Ajay was happiest in the company of his family and friends or immersed in a book, Sudoku or a crossword puzzle while listening to jazz. His love of golf was matched only by his passion for soccer, and he shared both with his son Amar and daughter Deeya. He and his wife Vasie also had a younger son named Arjun and an older daughter, Veena.

Described as a loving son, father and brother, with a heart of gold, Ajay was quite an adventurer. He hiked the peaks of the Drakensberg to train for his successful ascents of Mount Kilimanjaro and Machu Picchu. He had to abandon his Otter Trail trek on the penultimate day, when he dislocated his kneecap while climbing a rocky precipice along the Southern Cape coast. Despite this, he stayed on to greet his fellow hikers at the Storms River mouth with a six-pack of Black Label beer to celebrate their accomplishment. Ajay also enjoyed regular fishing with the Medics Angling Club, resulting in many a tall fishing tale that will be told for years to come!

Fiercely loyal, infuriatingly resolute and abundantly generous, Ajay stepped to the beat of his own drum. He sought the truth at all costs and claimed no easy victories. The measure of his life lies in the simplicity, humility and nobility of spirit for which he will always be remembered. He was a vocal member of the KZN Specialist Network, where his incisive questions and challenges at our academic meetings and annual general meetings will be very much missed. $\mathrm{He}$ was ever prepared to criticise the board of directors, and never spared any advice or recommendations to make the KZNSN a better organisation.

Ajay will be sorely missed by all our members, by his colleagues, and by the staff he worked with at Ethekwini Hospital in Durban. His indomitable spirit will forever live on in our midst. Rest in peace, Ajay.

\section{Executive Committee, KZN Specialist} Network

KwaZulu-Natal, South Africa info@kznspecialist.co.za

\section{Alewyn Petrus Rossouw}

Dit is met innige leedwese dat ek verneem het van Alewyn se dood. Op 27 Januarie 2015 sou hy 79 jaar oud geword. Alewyn kom vanaf Lydenburg, waar sy vader 'n gesinsdokter was. Sy moeder was 'n sjarmante dame vanaf Nederland, maar het goed hier ingeburger. Alewyn se ouer broer, Braam, was ook 'n algemene praktisyn en sy suster, Corrie, was getroud met ds. Punt Janson, wat later 'n parlementslid geword het.

Alewyn se ouers het op Graskop afgetree en ons het as koshuis-studente gereeld piesangs, lietsjies en pynappels vanaf hul plaas ontvang. Hierdie 'eksotiese' vrugte was 'n eienaardigheid vir ons Vrystaters met ons waatlemoene, pruime, kersies en perskes!

Alewyn was 'n briljante student. In sy eerste jaar het dr. B Cholnoky (plantkunde) rondgeloop met Alewyn se antwoordstel en verklaar: 'Hier is nou 'n papier', tewyl hy ander gewaarsku het: 'Menere, julle sal sak soos bakstene!.
Die eerste ses jaar van ons studie het maar redelik roetinegewys verloop. Ek en Alewyn was kamermaats vir'n hele aantal jare. Hy was besonder belese en kon interessant gesels oor etiek en filosofie. Hy was versot op O Henry en Damon Runyon se kortverhale en het later John Steinbeck bewonder en gelees.

Sy ware potensiaal het gou na sy huisdokterjare te voorskyn gekom en hy het kliniese assistent in neurologie geword. Hy het baie hoofstukke in akademiese boeke geskryf, bv. saam met prof. Ben Meyer (fisiologie). Hy was 'n gesogte mentor vir kliniese assistente in neurologie. Sover ek weet, was hy die eerste magisterstudent wat hierdie graad met lof geslaag het by Pretoria se Fakulteit Geneeskunde. Ironies genoeg is hy gediagnoseer met motorneuronsiekte, wat hom gou afgetakel het.

Hy was vir baie jare in vennootskap met $d r$. C Guldenpfennig ('Pennie') en het betreklik onlangs sy kliniese deel van die praktyk vaarwel geroep. Daarna het hy waardevolle werk gedoen as kundige met betrekking tot mediesgeregtelike neurologies-verwante gevalle.

Alewyn was 'n betroubare mens vir wie ek grenslose agting gehad het. Hy het onbaatsugtige diens aan sy medemens verskaf. Hy was ook minsaam, met' $n$ wonderlike humorsin.

Ons klasmaats, met wie ons op dieselfde verdieping in die mediese koshuis gebly het, sluit in Frik Booysen en Johan van Wyk, internasionaal bekende lewerchirurg. Johan was ook later hoof van die Departement Chirurgie by Tygerberg Akademiese Hospitaal.

Alewyn was getroud met Elna de Villiers en hulle het drie kinders gehad. Sy was oorspronklik 'n plaasnooi - ook uiters intelligent - en 'n steunpilaar in sy lewe.

Ons harte gaan uit na Elna, sy gesin en sy familie. Ons sal Alewyn nie vergeet nie.

\section{Prof. Ben Smit}

2de Laan 22, Melkbosstrand, Wes-Kaap, Suid-Afrika

bensmit@sonicwireless.co.za 